\title{
OBJEKTIVITÁS, NYITOTTSÁG ÉS TISZTESSÉG: AZ ELŐITEÉLETESSÉG KUTATÁSÁNAK LEGFŐBB TUDOMÁNYETIKAI DILEMMÁIRÓL
}

\section{OBJECTIVITY, OPENNESS AND HONESTY: THE MAIN SCIENCE ETHICAL DILEMMAS IN PREJUDICE RESEARCH}

\author{
Erdős Ákos \\ doktorandusz, egyetemi tanársegéd \\ erdos.akos@uni-nke.hu
}

ÖSSZEFOGLALÁS

A Magyar Tudományos Akadémia Etikai Kódexe, amely a tudományos kutatás területén kíván erkölcsi és etikai iránytǔként szolgálni, olyan kutatáshoz kapcsolódó etikai alapelveket fogalmaz meg, mint a tisztesség, megbízhatóság, objektivitás, pártatlanság és függetlenség, nyitottság, gondosság, elfogulatlanság, felelősség, valamint az önzetlenség alapelve.

Tanulmányomban ezen etikai alapelvek közül - a hazai és nemzetközi szakirodalom feldolgozásával - az objektivitás, a nyitottság és a tisztesség vonatkozásában vizsgálom meg azokat a dilemmákat, amelyek az előítéletes attitűdök tudományos vizsgálata kapcsán merülhetnek fel.

\section{ABSTRACT}

The Hungarian Academy of Sciences' Code of Ethics main task is to serve as a moral and ethical compass. The Code of Ethics sets out many ethical principles such as honesty, reliability, objectivity, impartiality and independency, openness, candour, responsibility, as well as altruism.

In this study we will examine, how objectivity, openness and honesty appear in studies of prejudice and prejudicial attitudes. We review them through processing of specialized Hungarian and foreign literature dilemmas where these ethical principles appear.

Kulcsszavak: előítélet, előítélet-kutatás, objektivitás, nyitottság, tisztesség, Magyar Tudományos Akadémia Etikai Kódex, etikai alapelv

Keywords: prejudice, prejudice research, objectivity, openness, honesty, Hungarian Academy of Sciences Code of Ethics, ethical principles 


\section{BEVEZETÉS}

Eredetileg hídépítésre szánta, végül mégis a magyar nyelv kifejlesztésére, a nemzetiség erősítése és pallérozása szent céljaira, a Magyar Tudományos Akadémia megalapítására ajánlotta fel birtokai évi jövedelmét gróf Széchenyi István 1825. november 3-án a pozsonyi országgyülés ülésén a következők előrebocsátásával: „T[isztelt] Statusok és Rendek! Én ugyan Nagy nem vagyok, de Vagyonos ember vagyok, azért Nemzeti Nyelvemnek gyarapítására egy egész Esztendei Jövedelmemet ajánlom, ugy hogy ennek a' kívánt Czélra való fordítása 's el rendelése mindenkor az Ország Gyűléstül függjön" (Szily, 1901, 607.). ${ }^{1}$

A Magyar Tudományos Akadémia (MTA) azóta is töretlenül folytatja tevékenységét a magyar nyelv ápolása és a tudomány szolgálata területén. A jogalkotó az Akadémia múködési és tevékenységi szabadságának törvényi oltalmazásához füződő társadalmi igény kielégítése érdekében 1994. április 26-án kihirdette a Magyar Tudományos Akadémiáról szóló 1994. évi XL. törvényt. A jogszabály az Akadémia közfeladatainak meghatározása alkalmával leszögezi, miszerint ezen intézmény: „őrködik a tudományos közélet tisztaságán, a tudományos kutatás és a tudományos véleménynyilvánítás szabadságán”. ${ }^{2}$

E feladat teljesítésének szellemiségében fogadta el 25/2010. (V. 4.) számú határozatával a Magyar Tudományos Akadémia Közgyülése az MTA Tudományetikai Kódexét (Tudományetikai Kódex). A dokumentum a tudományos kutatás területén kíván erkölcsi és etikai iránytüként szolgálni, s amelyben központi szerephez jutnak az olyan kutatáshoz kapcsolódó etikai alapelvek, mint a tisztesség, megbízhatóság, objektivitás, pártatlanság és függetlenség, nyitottság, gondosság, elfogulatlanság, felelősség, valamint az önzetlenség alapelve.

A következőkben ezen etikai alapelvek közül - a hazai és nemzetközi szakirodalom feldolgozásával - az objektivitás, a nyitottság és a tisztesség vonatkozásában vizsgálom meg azokat a dilemmákat, amelyek az elöítéletes attitüdök tudományos vizsgálata kapcsán merülhetnek fel. A felsorolt etikai alapelvek kiválasztása meglehet önkényesen történt, e választások oksági magyarázata ugyanakkor az, hogy álláspontom szerint, ezekkel kapcsolatban jelennek meg legmarkánsabban az elöítélet-kutatások dilemmái.

\footnotetext{
${ }^{1}$ Gróf Lónyay Menyhért visszaemlékezése szerint Széchenyi felszólalása a következők szerint hangzott el: „Szabad legyen nekem felkelnem, szabad szólanom nekem, ki a förendek táblájához tartozom, a tek. statusok és rendek gyülekezetében. Meg vagyok tökéletesen győződve annak hasznáról és a nyelvre való nézve buzgó sikeréről, mit Sopronvármegyének nagyérdemü követe, Nagy Pál proponált, s ezen czélra a tek. statusok és rendek előtt az én egész birtokomnak egy évi jövedelmét felajánlom.” Elnöki megnyitó beszéd Gróf Lónyay Menyhérttől (Lónyay, 1873, 3-10.).

${ }^{2}$ 1994. évi XL. törvény a Magyar Tudományos Akadémiáról, 3. § (1) bek. g) pont.
} 


\section{OBJEKTIVITÁS}

A Kutatásetikai Kódex 2.3. pontja szerint: „,az értelmezések és a következtetések levonása kizárólag tényeken vagy elfogulatlan és logikus bizonyításon alapulhat, valamint olyan adatokon, amelyek helyessége legalább elméleti szinten ellenőrizhetö" (Fésüs, 2010, 19.).

Számos esetben megfogalmazták már, hogy a tudomány, a tudományos igényü gondolkodás és kutatás egyik meghatározó általános jellemzője az objektivitás, valamint az előítéletektől mentes, elfogulatlan eredményteremtés (Nahalka, 1995). Ilyetén természetesnek és magától értetődőnek tủnik, hogy az elöítéletek, illetve az elóítéletesség vizsgálatára irányuló tudományos munkákkal szemben is megjelennek ezek az elvárások. Mindazonáltal, e kijelentés azonnal ellentmondásokat ébreszthet abban, aki e terület kutatására adja a fejét. Ennek oka pedig a következők szerint foglalható össze.

Az elöítéletek vizsgálatával foglalkozó szakirodalomi forrásokban számos esetben találkozunk azzal a megcáfolhatatlan ténnyel, miszerint az elöítéletek részei, hovatovább funkcionális részei életünknek (Allport, 1977; Fehér, 2017). Következésképpen, az elöitéletek minden formájától mentes élet aligha képzelhető el. Martin Heidegger Bevezetés a fenomenológiai kutatásba címü munkájában ezzel összefüggésben megjegyzi: „az az elgondolás, miszerint az embernek nincsenek elöítéletei, maga a legnagyobb elöítélet. [...] Nem az elöítéletektől kell megszabadulnunk, hanem azon lehetőségek számára kell szabaddá válnunk, amelyek hatására a döntő pillanatban az adott dologgal szembeni elö́téleteinket feladhatjuk. Ebben rejlik a tudomány emberének egzisztenciaformája" (Heidegger, 2005, 2.). Talán éppen ezért, a normatív elöítélet-elméletek képviselői azt vallják, hogy kizárólag a negatív elöítéletekkel szükséges foglalkoznunk.

Felmerül tehát a kérdés, hogy miként lesz elöítéletektöl mentes, illetve teljesen objektív az a kutató, aki ebben vagy más tudományos témában vizsgálódik? A válasz kézenfekvőnek tủnik: feltehetőleg sehogy. Ezzel kapcsolatban Gordon Allport, az előítéletek neves kutatója így ír: „még a tudós is nehezen képes szigorú objektivitásra a nemzeti és faji különbségek dolgaiban. A tudós sem mentes a különféle pozitív és negatív elöítéletektől, melyekkel meg kell vívnia a harcot. Azt viszont nem tudja, hogy elöítéletei milyen mértékben befolyásolják a bizonyítékok által érvényesnek tartott értelmezését" (Allport, 1977, 142.). Heidegger filozófiai megközelítése pedig egyenesen kizárja azt, hogy az értelmező szubjektum, elözetes értékelési szempontjainak, illetve előzetes ítéleteinek érvényesülése nélkül fogalmazza meg gondolatait. Ugyanis minden értelmezésnek szükségszerủen meg kell értenie az értelmezendőt, így előzetesen bírnia is kell azzal. Heidegger szerint az értelmezések kapcsán „objektivitásról” eleve okafogyott volna beszélni, ha közben épp az értelmező alanyt, s annak előzetes véleményeit, illetve feltételezéseit akarjuk kirekeszteni vagy mellőzni (Fehér, 2017). 
A dilemmákat ébresztő másik gondolat szorosan kapcsolódik az előzőhöz. A tudományos igényü kutatómunkákkal szembeni következetes elvárás általában az, hogy azokban a szerző saját hipotéziseket (esetleg kérdésfelvetéseket) fogalmazzon meg, illetve munkájával valamilyen nóvumot teremtsen. „A hipotézis egy olyan kijelentés, amely a kutató feltételezéseit fejezi ki a problémában szereplő változókra, azok kapcsolatára vonatkozóan" (Falus, 2004, 9.). Mit is állítunk ezzel? Azt, hogy a kutatás egy olyan feltételezésre épül, amely a kutatóban még azelőtt alakul ki, hogy annak helyességét illetően közvetlen, megalapozott információk állnának rendelkezésre. A hipotézis tehát legmélyebb lényege szerint közvetett, illetve nem tényszerü, bizonyított adatokon alapuló elózetes feltevést jelent, amelyet a vizsgált csoport vonatkozásában a kutatás elején elfogadottnak tekintünk. Az előző gondolattal persze kifejezzük, hogy a hipotézisben megfogalmazottak nem puszta intuíciókon alapuló megállapítások, hiszen a kutató elözőleg táplálkozott a témában készült eredményekből és szakirodalmi forrásokból. Mindazonáltal azt sem állíthatjuk, hogy a hipotézis szilárd tényeken alapuló felvetés, mivel ebben az esetben a kutató által begyüjtött adatokon alapuló, „objektív" megállapítások nem hoznának újító eredményt.

Finszter Géza helyesen állapítja meg, mikor kijelenti: ,a hipotézisnek nem az a feladata, hogy elörevetítse a kutatás végeredményét, hanem az, hogy tervezhetövé tegye a munkát", ennélfogva egy hipotézis akkor megfelelö, ,ha alkalmat ad a kiinduló feltevések rendszeres ellenőrzésére és korrigálására, [és] ha végül elvezet a valóság helyes megismeréséhez" (Finszter, 2018, 385.). Ezzel együtt ugyanakkor Finszter is felhívja a figyelmet arra, hogy a kutató hipotéziseit annak saját előítéletei könnyen befolyásolhatják (Finszter, 2018).

Következésképpen, amikor az elöítéletek vizsgálata alkalmával felállítjuk hipotéziseinket, az ott tett megállapítások valójában a saját előítéleteink reprezentációi lesznek a vizsgált csoporttal szemben. Ilyenkor ugyanis az elöítéletesség feltételezése a vizsgálat alanyairól tulajdonképpeni előítéletnek tekinthető velük kapcsolatban. Erős Ferenc szerint éppen ez vezet oda, hogy valójában nincs értékmentes előitélet-kutatás, hiszen a kutató által helyesnek vélt ítélete által a kutatás alanyai maguk is stigmatizálódhatnak, elöítélet tárgyává válhatnak (Erős, 2005).

Az objektivitásra törekvés megnyilvánulásának egy másik színtere a kutató által alkalmazott eszközök megválasztása. A kvantitatív és kvalitatív kutatások, illetve módszerek szembeállítása kapcsán sokszor fogalmazódik meg az a feltevés, miszerint a statisztikai adatokon alapuló, kérdöíves, feladatlapos, tesztmódszerrel végzett kvantitatív mérések objektívebb eredményeket adnak a kvalitatív módszerekhez képest (Gárdos, 2011). Ezen megközelítések szerint a kvalitatív kutatásokra tehát inkább jellemzö, hogy azok nem lehetnek semlegesek, objektívek és teljesek. A kvantitatív kutatások esetében ugyanakkor a kutató személyének - elméletileg - kisebb a jelentősége, ezáltal értéksemlegesebb lehet a megközelítés. 
A kvantitatív kutatási módszerek objektivitásába vetett feltétel nélküli hit ugyanakkor sokszor félrevezet, és indokolatlan megnyugvást biztosít. Gárdos szerint ,a kérdések megfogalmazása, a kérdezési szituáció, az adatok kódolásának módja, a változók létrehozása és nem utolsósorban a statisztikai módszerekkel történő adatelemzés mind-mind »szubjektiválja« az ideálisnak tételezett »objektív« tudományos megismerést” (Gárdos, 2011, 126.).

Mi több, az elöítéletes attitüdök vizsgálatával foglalkozó kvantitatív kutatások által alkalmazott kérdőívek sok esetben alaptalan következtetésekhez vezetnek az elöítéletességből származó kirekesztés és megkülönböztetés (diszkrimináció) mértékének és okainak tekintetében (Erőss-Gárdos, 2007).

A kutatások során alkalmazott kvantitatív módszerek tehát önmagukban semmiképp nem alkalmasak arra, hogy teljes mértékben kizárják a kutató szubjektumát.

Kutrovátz Gábor és munkatársai az objektivitás vakfoltjaival kapcsolatban ugyanakkor figyelmeztetnek a következőkre: ,azt tudni, hogy semmilyen módszer nem biztos, semmilyen összehasonlítás nem teljesen elöítélet-mentes (objektív), még messze nem jelenti azt, hogy minden mindegy" (Kutrovátz et al., 2008, 50.). A fent említett dilemmák tehát nem zárják ki, hogy az elóitéletesség kutatása során jóhiszemüen és a Tudományos Akadémia által megfogalmazott objektivitás szempontjait figyelembe véve járjunk el. A kutatásainkat megindító hipotéziseink, amelyek feltételezik a témában szerzett elözetes ismereteket, szükségszerüen előfeltevésekre épülnek. Nem létezik semmiből vett tudás, nem létezik cognitio ex nihilo. Immanuel Kant szerint éppen azért vagyunk képesek filozofálni, mert előzetes ítéletekkel rendelkezünk.

Az elöítéletek, elöítéletes attitüdök vizsgálatának talán egyik legérzékenyebb kérdése az, hogy miként váljon a kutató és maga a kutatás előitéletektől mentessé, objektívvá és elfogulatlanná. Úgy vélem, hogy ilyenkor a legjobb esetben is az elöitélet-mentesség és az objektivitásra törekvés lehet a cél. Fehér szerint: „az egyetlen következetes módja annak, hogy elöítélet-mentesek legyünk, ebböl a hermeneutikai szempontból az, hogy semmivel szemben sem tápláljunk elöitéletet, még magukkal az elöítéletekkel szemben sem, vagyis ne utasítsuk el vakon őket, hanem vessük alá a kritikai vizsgálatnak” (Fehér, 2017, 23.).

Az objektivitásra törekvés igénye a személy tekintetében tehát elsősorban akképp valósulhat meg, hogy a kutató az eredmények tükrében képessé teszi magát arra, hogy elfogadja hipotéziseinek esetleges cáfolatát, s azokat kritikusan vizsgálja. Még akkor is, ha úgynevezett nullhipotézisről (null hypothesis) van szó, amelyet a hipotézis megfogalmazása idején alapvetően nincs okunk megkérdöjelezni. Ezzel kapcsolatban hívja fel a figyelmet az Akadémia Tudományetikai Kódexe is arra, hogy a kutatási eredmények közlésekor „nem engedhető meg az adatok önkényes szelektálása, nem szabad elhallgatni a következtetésekkel összhangban nem álló eredményeket" (Fésüs, 2010, 24.). 
Az elöítélet-mentes, objektív szemléletre törekvő kutatás módszereinek tekintetében pedig a meghatározónak és követendőnek az tünik, hogy a módszerek helyes megválasztásával létrehozott eredményeinket úgy közöljük, hogy azokban prekoncepcióink ne okozzanak torzítást.

Az előítéletektől mentes kutatásokra jellemző tendenciák kapcsán Allport pozitívan fogalmaz: „,biztató jel mindenesetre, hogy a társadalomtudósok manapság jóval inkább tudatában vannak ennek a veszélynek [hogy az elöítéletesség öket is jellemzi], mint hajdanában" (Allport, 1977, 142.).

\section{NYITOTTSÁG}

Az MTA Tudományetikai Kódexe szerint a nyitottság elvárása azt jelenti, hogy a kutató eredményeinek megbeszélésekor és az eredmények publikálása során nyitott a tudomány képviselőinek érdeklődése felé, ezzel is hozzájárulva a közös tudáskincs gyarapításához. „A nyitottság feltételezi a tudományos közleményben közzétett eredményeket alátámasztó adatok nyilvánosságát és hozzáférhetőségét minden érdeklődő kutató és a közvélemény számára. Ezt az alapelvet indokolt esetben korlátozhatják a kutatás jellegéből adódó speciális szempontok (iparjogvédelem, személyiségi jogok védelme stb.)" (Fésüs, 2010, 19). A tudományos munkák tekintetében természetes az az elvárás, hogy az újonnan megteremtett ismeretek közreadásával bővítsük a közösségi tudásvagyont. A nyitottság elvárása ugyanakkor nehézségek elé állíthat bennünket azokban az esetekben, amikor a kutatás alanyai olyan egyének, csoportok, amelyek a közösség bizalmának élvezői, s e bizalom nélkül társadalmi szerepükben impotenssé válnának, rendeltetésüknek alig vagy csak korlátozottan lennének képesek eleget tenni (például: rendészeti szervek állománya, egészségügyi dolgozók, közoktatásban dolgozók), a kutatás tárgya pedig olyan jelenségek vizsgálata, amelyek általában a társadalom rosszallását váltják ki (például: előítéletesség, különböző devianciák), ezáltal alkalmasak arra, hogy az egyénnel, illetve csoporttal szemben fennálló társadalmi bizalmat gyengítsék, megingassák.

Ilyenkor a tudományos munkák nyitottságához füződő társadalmi érdek, illetve az adott csoporttal szemben fennálló társadalmi bizalom megörzéséhez füződö érdekek összefeszülhetnek, s dilemmákat ébreszthetnek. Kiváltképp, ha a kutató maga is az adott csoporthoz tartozik, ami már a pártatlanság és függetlenség tudományetikai kérdéseit is felveti. ${ }^{3}$

${ }^{3}$ Az MTA Tudományetikai Kódexének 2.4. pontja szerint: „Pártatlanság és függetlenség bármely érdekelt féltől vagy csoportérdektől, ideológiai vagy politikai nyomásgyakorlóktól, gazdasági vagy pénzügyi befolyástól.” (Fésüs, 2010, 19.) 
A fentiekkel összefüggésben példaként említhetjük meg azokat a vizsgálatokat, amelyek orvosok körében elemezték az addikciós betegekhez füződő viszonyulást (Barth et al., 2007). Ezen kutatások rávilágítottak arra, hogy azok a személyek, akiktől alapvetően azt várja el a társadalom, hogy elöítéletektől mentesen, elfogulatlanul segítsenek a beteg embereken ${ }^{4}$, sok esetben elutasító attitüddel, hiányos tudáson alapuló prekoncepciókkal, elöítéletekkel felruházva közelítették meg az olyan mentális betegségeket, mint a nikotinfüggőség, alkoholizmus vagy más pszichoaktív szer okozta addikciók.

Tekintve, hogy az egészségügyi ellátásban a szakember és páciens kapcsolatának, egymáshoz történő viszonyulásának és kommunikációjának a hatékony gyógyításban fontos szerepe van (Rózsa, 2017), felmerül a kérdés, hogy miként kezeljük azokat a kutatási eredményeket, amelyek esetlegesen ennek a bizalmi kapcsolatnak a kialakítását nehezítik, horribile dictu ellehetetlenítik.

Hasonló problémákkal találkozhatunk a rendészeti szervek viszonylatában is, hiszen a demokratikus jogállamokban - elméletileg - a hivatásos állomány tagjai mindamellett, hogy a legitim kényszer alkalmazói, egyúttal a köz bizalmának feltétlen élvezői is (Erdős, 2015). Mitévők legyünk tehát azokkal a vizsgálati konklúziókkal, melyek például a rendőri tevékenységben, képzésben megjelenő elöítéletességre, visszaélésekre rávilágítva (Csepeli et al., 1997) rombolhatják a rendészetbe vetett társadalmi bizalmat?

Úgy vélem, hogy a fenti dilemmák feloldásához a társadalmi érdekek mérlegének serpenyöjébe, a kutatásetikai szabályok által megfogalmazott nyitottság mellé el kell helyeznünk a vizsgálat nyújtotta önreflexió lehetőségét is. A korábban hivatkozott szerzők több esetben is kiválóan világítanak rá arra, hogy az általuk vizsgált - esetleges bizalomvesztésre okot szolgáltató - jelenségek feltárása önmagában lehetőséget nyújt a csoport önreflexiós és - ha úgy tetszik - „önmedikalizáló”, önreparációs folyamatainak beindítására. Így különösen az attitüdformálás, a képzés, oktatás átalakításának, kibővítésének és aktualizálásának szorgalmazása által (Barth et al., 2007). A változáshoz, az eredményesebb közösségi szolgálathoz füződő társadalmi érdekkel tehát a nyitottság, a kutatási eredményeknek a széles körủ publikálása egyértelmüen billenti el a társadalmi érdekek mérlegének nyelvét.

\section{TISZTESSÉG}

A Magyar Tudományos Akadémia Tudományetikai Kódexe szerint tisztességgel kell eljárni „,a tudományos célok és a kutatási szándékok ismertetésében, a tudományos módszerek, eljárásmódok és megalapozott értelmezések szabatos bemu-

\footnotetext{
${ }^{4}$ Lásd A Magyar Orvosi Kamara Etikai Kódexe (MOK, 2011).
} 
tatásában, továbbá az eredmények alkalmazásában rejlő lehetőségek, veszélyek és jogosnak tekinthető igények világossá tételében" (Fésüs, 2010, 18.).

Általános tudományetikai és kutatásmódszertani elvárás, hogy egy vizsgálat - legyen szó kvalitatív vagy kvantitatív módszer alkalmazásáról - minden esetben a kutatási célok megjelölésével kezdődik. Mindezek mellett ugyanakkor továbbra is az az irányadó, hogy a kutatás a célok tisztázását követően is reális (objektív) képet fessen a vizsgálat tárgyává tett jelenségekről. Az elöítéletes attitüdök vizsgálata alkalmával e ponton újabb dilemmával szembesülünk. Hiszen függetlenül attól, hogy az elöítéletek valamilyen formában mindenkiben jelen vannak, azokat felvállalni általában senki nem szereti. Ennek alapvető oka - ahogy arra a korábbiakban már kitértem - az előítéletességgel szembeni elöítéletekben rejlik. Hans-Georg Gadamer szerint: „a felvilágosodás alapvető előítélete abban áll, hogy elöítélettel viseltetik egyáltalán mindféle elóítélettel szemben" (Gadamer, 1984, 194.).

Felmerül tehát az újabb kérdés, miként közöljük kutatási céljainkat anélkül, hogy azzal a vizsgálat eredményei - a kutatásban részt vevők kognitív torzításai által - ne váljanak értékelhetetlenné, illetve valótlanná? Különösen fontos lehet ez a korábban már említett, társadalmi bizalmat élvező csoportok esetében.

Úgy vélem, hogy ilyenkor - az indirekt kérdésfelvetések, az utólagos tájékoztatás alkalmazásának lehetőségei mellett - a kutató alapvetően a vizsgált alanyok őszinteségére számíthat. A Tudományos Akadémia Kutatásetikai Kódexe nem tartalmaz olyan kitételt, amely felmentést adna a tisztességes eljárás és a tájékoztatáshoz füződő érdekek érvényesülése alól. A kódex bevezető gondolataiban megfogalmazásra kerül, miszerint ,a tudományos kutatás célja a tanulmányozandó tárgy, jelenség természetének és alapelveinek megismerése, a kutatási eredmények nyilvánosságra hozatala" (Fésüs, 2010, 8.). Ilyeténképpen el kell fogadni, hogy az elöítéletek, a különböző csoportokkal, devianciákkal, betegségekkel szemben fennálló előítéletes attitüdök vizsgálatakor mindenkoron számítani kell a kutatásban részt vevő alanyok kognitív torzításaival.

\section{ÖSSZEGZÉS}

E dilemmák felvetése korán sem azt jelenti, hogy az elöítéletesség vizsgálatára irányuló kutatások ne felelhetnének meg az Akadémia Tudományetikai Kódexének. Mi több, e téma érzékenysége okán a tudományos erkölcsi, etikai alapelvek érvényesülése még inkább jelentőséghez jut. Valcsicsák Imre szerint a társadalom mechanizmusában az erkölcs alapvetően azért jött létre és azért létezik, hogy a maga módján, sajátos eszközrendszerével hozzájáruljon az emberek lehetőség szerinti minél jobb létéhez, együttmúködésük optimális harmóniájához (Valcsicsák, 2013). Úgy vélem, joggal állíthatjuk tehát, hogy a tudományetikai alapelvek 
is azért születnek, léteznek, s irántuk azért táplál fokozott igényt a társadalom, mert azoktól a tudomány, végső soron pedig a közösség fejlődését várja.

Az erkölcsi szabályok érvényesülése az egyén és a közösség önszabályzó mechanizmusának egyik, ha nem a legjelentősebb eszköze. Az írott normával szembeni előnyét elsősorban az adja, hogy kikényszerítésének eszköze, magában az egyénben és nem külső (hatalmi) forrásokban rejlik. Kant megfogalmazásában: „a törvény szerint valaki akkor bünös, ha megsérti mások jogait. Az etika szerint akkor, ha fontolgatja, hogy megteszi azt" (idézi: Hoffman et al., 2016, 295.).

Kant gondolatai mentén a tudományetikai alapelvek legföbb gyakorlati haszna a következők szerint foglalható össze. Az etikai alapelvek érvényesülése - kutatási területtől, a kutatott alanyoktól és jelenségektől függetlenül - mindamellett, hogy megerösítik a tudományba, illetve a tudományos kutatásokba vetett társadalmi bizalmat, megóvnak attól, hogy a kutató írott jogi normákat sértsen, közvetve tehát kárt okozzon a tudomány nevében.

\section{IRODALOM}

Allport, G. W. (1977): Az elöitélet. (ford. Csepeli Gy.) Budapest: Gondolat Kiadó

Barth Á. - Demetrovics Zs. - Bognár G. (2007): Drogfüggő betegek kezelésével kapcsolatos ismeretek és attitüdök vizsgálata pszichiáter szakorvosok körében. Mentálhigiéné és Pszichoszomatika, 8, 3, 179-192. http://real.mtak.hu/58198/

Csepeli Gy. - Örkény A. - Székelyi M. (1997): Szertelen módszerek. A megkülönböztetésmentes viselkedés lehetőségei és akadályai (Előzetes kutatási jelentés 1996-1997). In: Csányi K. (szerk.): Szöveggyüjtemény a kisebbségi ügyek rendörségi kezelésének tanulmányozásához. Budapest: COLPI Kiadó

Erdős Á. (2015): NAV-MEDIC - Rendészeti ellátás múltja és jelene. Vám-Zoll, 1, 11-14. https:// bit.ly/2UGelTn

Erős F. (2005): Az elöítélet-kutatás dilemmái. In: Keményi M. - Szalai J. (szerk.): Kisebbségek kisebbsége. A magyarországi cigányok emberi és politikai jogai. Budapest: Új Mandátum Kiadó, https:/www.sulinet.hu/oroksegtar/data/magyarorszagi_nemzetisegek/romak/kisebbsegek_kisebbsege/pages/kk_11_eros.htm

Erőss G. - Gárdos J. (2007): Az előítélet-kutatások bírálatához. A „rasszista” nyugdíjasoktól a kirekesztő iskolásokig. Educatio, 16, 1, 17-37. http://www.hier.iif.hu/hu/letoltes.php?fid=tartalomsor/411

Falus I. (szerk.) (2004): Bevezetés a pedagógiai kutatás módszereibe. Budapest: Müszaki Könyvkiadó, https://www.tankonyvtar.hu/en/tartalom/tamop425/2011_0001_531_pedagogia/2011_0001_531_pedagogia.pdf

Fehér M. I. (2017): Az elöítéletek mint a megértés feltételei. Magyar Filozófiai Szemle, 61, 1, 9-28. https://bit.ly/2UG8E8b

Fésüs L. (szerk.) (2010): Tudományetikai kódex. Budapest: Magyar Tudományos Akadémia, http:// old.mta.hu/data/cikk/11/97/91/cikk_119791/etikai_kodex_net.pdf

Finszter G. (2018): Rendészettan. Budapest: Dialóg Campus Kiadó, https://akfi-dl.uni-nke.hu/ pdf_kiadvanyok/web_PDF_EKM_Rendeszettan.pdf

Gadamer, H.-G. (1984): Igazság és módszer. (ford. Bonyhai G.) Budapest: Gondolat Kiadó 
Gárdos J. (2011): Interjús szociológiai források újrafelhasználása. Szociológiai Szemle, 21, 3, 125 145. http://www.szociologia.hu/dynamic/06_gardos.pdf

Heidegger, M. (2005): Introduction to Phenomenological Research. Bloomington-Indianapolis: Indiana University Press

Hoffman, M. - Yoeli, E. - Navarrete, C. D. (2016): Game Theory and Morality. In: Shackelford, T. K. - Hansen, R. D. (eds.): The Evolution of Morality. Switzerland: Springer DOI: 10.1007/9783-319-19671-8_14, http://www.cdnresearch.net/pubs/private/Hoffman_Morality_2016.pdf

Kutrovátz G. - Láng B. - Zemplén G. (2008): A tudomány határvonalai. Budapest: Typotex Kiadó

Lónyay M. (1873): A Magyar Tudom. Akadémia Évkönyvei. Tizennegyedik kötet, 1873-1875. 3-10. Pest: Eggenberger

MOK - A Magyar Orvosi Kamara Etikai Kódexe. Elfogadta a Magyar Orvosi Kamara Küldöttközgyűlése 2011. szeptember 24-én. A törvény értelmében hatályba lép 2012. január 1-jén. https:// mok.hu/public/media/source/etikaiKodex/kodex141128.pdf

Nahalka I. (1995): A természettudományos nevelés és a tudományelméletek. Magyar Pedagógia, 95, 3-4, 229-250. http://www.magyarpedagogia.hu/document/3_108_Nahalka\%20Istvan.pdf

Rózsa E. (2017): Deficitek az orvos-beteg/páciens kapcsolatban - esélyek és lehetőségek bioetikai és egészségszociológiai vizsgálatok metszéspontjain. Metszetek, 6, 2, 203-227. http://metszetek.unideb.hu/files/tanulmany_203-227.pdf

Szily K. (szerk.) (1901): A M. Tud. Akadémia jegyzőkönyvei. Jegyzőkönyvi mellékletek. Akadémiai Értesitó, 12, 133-144, 602-614. http://real-j.mtak.hu/82/1/AkademiaiErtesito_1901.pdf

Valcsicsák I. (összeáll.) (2013): Rendészeti (szakmai) etika. Budapest: Nemzeti Közszolgálati Egyetem Kiadó, https://rtk.uni-nke.hu/document/rtk-uni-nke-hu/etika-jegyzet.original.pdf 